\title{
STOOL ANTIGEN (HPSA) TEST IN DETECTION OF HELICOBACTER PYLORI INFECTION AMONG ADULT DYSPEPTIC PATIENTS IN TRIPOLI, LIBYA
}

\author{
*G.M. Huwiage ${ }^{1}$, A.A. Nami ${ }^{2}$, A.H. Akadh ${ }^{3}$ \\ 1 - HIGH INSTITUTE OF MEDICAL SCIENCES\& TECHNOLOGY, ALGARABOLLI, LIBYA \\ 2 - AL-MERGIB UNIVERSITY, AL KHUMS, LIBYA \\ 3 - MEDITERRANEAN SPECIALIZED CLINICS, TRIPOLI, LIBYA
}

Background. Helicobacter pylori is the most common infection in the world. Relationship between H. pylori and dyspepsia was confirmed by many studies, it has been strongly associated with peptic ulcer disease and gastric cancer. In that respect, several invasive and noninvasive methods for the diagnosis of $\mathrm{H}$. pylori infection were utilized.

Objective. The aim of the study was to evaluate the association between dyspepsia and the positivity of $H$. pylori stool antigen test, to compare this test with serological IgG test.

Methods. 125 adult patients were randomly selected from gastroenterology units of Mediterranean and Tajurah clinics in Tripoli. Stool samples were taken for detection of $\mathrm{H}$. pylori antigen by enzyme immunoassay. Blood samples for detection of anti-H. pylori IgG antibodies were taken. Data were statistically analyzed using SPSS.

Results. 125 dyspeptic patients: 47 male and 78 female, aged 18-83 years old were examined. 80 patients were infected by $\mathrm{H}$. pylori that was proved by a positive stool test, 88 had a positive IgG test. The prevalence was higher in the patients aged 28-47 years old. There was substantial relation to age, marital status and economic risk factors; there was no association between $\mathrm{H}$. pylori and gender, sources of drinking water, living standards, smoking, family history of peptic ulcer, drug consumption, and blood groups.

Conclusions. Relatively high rates of detection by HpSA prove that stool testing might be a reliable, simple, inexpensive, and non-invasive alternative test aщк detectumm of $\mathrm{H}$. pylori, diagnosing active infection and confirming cure. However IgG test has a low sensitivity, specificity, and accuracy compare to the HpSA test. Thus it can be used for screening purposes.

KEY WORDS: Helicobacter pylori; dyspepsia; enzyme immunoassay; stool antigen test.

\section{Introduction}

The main definitive events of our knowledge of $H$. pylori came in 1979-1982 by the basic experiments of the pathologist Robin Warren, who identified the bacterium, and Barry Marshall, who successfully cultured the bacterium. In their experiments, they emphasized the association of $H$. pylori with Gastroduodenal diseases. In the end, the World Health Organization classified $H$. pylori is a class I carcinogen in 1994 due to its definite carcinogenic potential in humans [1]. H. pylori is a gram-negative spiral shaped, microaerophilic, and slowly growing bacterium. H. pylori-colonize the human stomach mainly in the mucus layer, rarely adhere to the mucosal cells, or intracellular. It is motile due to the presence of a tuft of polar flagella; moreover, it holds an important acid resistance

*Corresponding author: Goma Mohamed Huwiage, Ph.D., Assistant Professor, Department of Medical Microbiology, High Institute of Medical Sciences and Technology, Algarabolli, Libya.E-mail: gomanagoma96@yahoo.com mechanism through the generation of urease enzyme [2]. One of the principal structural parts of $H$. pylori is the flagella; it has unipolar flagella developed to move through the mucus barrier toward the gastric epithelial surface for colonization [3]. The other structural component is the outer membrane proteins (OMPs), these surface proteins have a specific important adhesive virulence factor that can bind to receptors on the surface of the gastric mucosa. One of these factors is the BabA (blood group antigen-binding Adhesion) [3]. The other OMP adhesion is the Sialic acid binding Adhesion $(S a b A)$. Bab $A$ and Sab $A$ adhesions are usually linked to increased risk of Gastro duodenal diseases [2]. Lipopolysaccharide (LPS) is another its structural element. It is significant in the integrity of the cell envelope of Gram-negative bacteria; besides, it can affect the severity and chronicity of infection [4]. The most significant structure of $\mathrm{H}$. pylori is the genome. There are 
two independent $H$. pylori genomes, that have been completely sequenced the $H$. pylori 26695 and $H$. pylori j99 genomes, although the 26695 genomes was $24 \mathrm{~KB}$ larger, both the J99 and 26695 genomes possessed a total $(\mathrm{G}+\mathrm{C}) \%$ of $39 \%$. H. pylori have small genome $(1,667,867$ base pair for 26695 type while, it is 1.643 .831 for $J 99$ type). This genome accommodates about 1,500 genes [5]. Virulence by definition is the ability of pathogens cause disease, and factors associated with this virulence are virulence factors. H. pylori virulence factors that are positively correlated with gastrointestinal diseases include structural, as well as secretory components. Structural components include LPS, OMPs, flagella, and the type IV secretion system (T4SS); however, its secretory components involve ammonia by urease, cytotoxinassociated gene $A(\operatorname{Cag} A)$, Vaculating cytotoxin $(\operatorname{vac} A)$, and other secretory enzymes [6]. The prevalence of $H$. pylori among adults is $\sim 30 \%$ in the United States and other developed countries, while it is more than $80 \%$ in most developing countries $H$. pylori are usually acquired in childhood [2]. Newly published two studies in African countries, reported that the prevalence of $H$. pylori infection is yet high in Morocco and Ethiopia (75.5\% and $67.7 \%$ respectively), both surveys demonstrated a significant correlation with age. Another survey in Nigerian dyspeptic patients found that the prevalence was $93.6 \%$ by the serology test. These surveys showed that the prevalence was still high in this region; however, it looked lower in the western developed world in spite of higher rates among immigrants coming from countries with a high prevalence of $H$. pylori [7]. Regarding important risk factors, it was accounted for that the prevalence of $H$. pylori was positively correlated with the living in rural areas, bad sanitary status, overcrowding, low educational level, and poor socioeconomic conditions [7]. Transmission of the infection probably occurs in multiple pathways, which may differ in various societies and age groups, [8]. It has been established that there is still contention about the actual mode of transmission of $H$. pylori infection, although Person-toperson transmission through fecal-oral or oraloral routes has been emphasized by many studies [9]. Oral-oral route of transmission depends on the presence of $H$. pylori in the gastric juice, so could reach the oral cavity through reflux or vomitus. An early study reported that $H$. pylori can be cultivated from vomitus, as a result, $H$. pylori are potentially transmissible during gastrointestinal diseases, especially, during vomiting [9], and moreover, it has been shown that $\mathrm{H}$. pylori could be transferred through contact between persons, particularly, during childhood. The primary path of transmission is regarded through oraloral, fecal-oral, or gastric-oral. Nevertheless, the route of transmission appears to be different, between developing, and developed countries, because the age, race, and socioeconomic status are changeable [7]. Dyspepsia could be separated into two types: ulcer dyspepsia (UD) related to organic cause and nonulcer dyspepsia (NUD) also known as Functional dyspepsia (FD), which is specified as chronic dyspepsia without organic disease [10]. For diagnosis, functional dyspepsia has been described that the patients higher than 55 years old, or those with alarm features such as GIT bleeding, weight loss, family history of gastric cancer, should undergo quick endoscopy to exclude organic diseases; nevertheless, in patients aged 55 years or younger with no alarm features, the clinician may consider testing and treat strategy using a non-invasive test for H.pylori diagnosis followed by the treatment of the H. pylori positive patients. It was recognized that the test and treatment option was preferable in populations with a moderate to high prevalence of $H$. pylori infection ( $\geq 10 \%)$ [11]. The rapid HpSA test based on ICA methods was more recently developed and had been used for the detection of $H$. pylori infection before and for follow up after the treatment; nevertheless, the accuracy of the rapid HpSA test is comparable, or a slight bit lower than the standard HpSA test [12]. The most distinct indications for treatment of $H$. pylori infection are those related to duodenal or gastric ulcers regardless of their activity status; other important indications are patients with low-grade gastric $B$ cell lymphoma and after gastric cancer resection, however, many guidelines now recommend H. pylori treatment in uninvestigated simple dyspepsia following noninvasive diagnosis, also recommend treatment in functional dyspepsia although, it was proved that only $5-10 \%$ of patients get benefit from such treatment [2].

Combination regimens were developed to overcome the resistance to monotherapy. While, the best option is doing antibiotic sensitivities, but it is difficult and expensive and usually not indicated unless there is a failure of the second line of the treatment regimen. The recommended treatment regimen for $\mathrm{H}$. pylori infections are the first line regimen involving 
the usage of three drugs: Omeprazole, Clarithromycin, and Amoxicillin for 7-14 days; or the use of Omeprazole, Clarithromycin, and Metronidazole for 7-14 days. The second line suggests the use of four drugs: Omeprazole, Bismuth subsalicylate, Tetracycline and Metronidazole for 14 days [2].

The objectives of the study were to determine the prevalence of $H$. pylori among adult dyspeptic patients in Tripoli region and to evaluate the performance of stool antigen test (HpSA) as a diagnostic method for the detection of $H$. pylori infection; to compare (HpSA) test with IgG antibody test regarding sensitivity, specificity, accuracy and their useful applications; to determine the relationship of a proposed risk factor with $\mathrm{H}$. pylori infection in the studied group.

\section{Methods}

Research design. The work was a crosssectional study conducted to find out the prevalence of $H$. pylori among the dyspeptic patients admitted to the gastroenterology units of the Mediterranean and Tajurah specialized clinics in Tripoli from January to April 2017. Labbased stool examination was carried out to collect data on the prevalence of $H$. pylori. In addition to this, data on risk factors were gathered from the study population using a questionnaire survey, which was focused on associated factors contributing to $\mathrm{H}$. pylori infection. But the serological IgG antibody test was applied to all the participants for comparison with the HpSA test.

Patients. In three months, (January to April 2017), one hundred and twenty-five different patients were selected randomly from those, who were attending gastroenterology units of the Mediterranean and Tajurah specialized clinics in Tripoli city. All patients with complaints of dyspepsia were enrolled in this study.

Sample size. Blood and stool samples were collected from all participants (125 randomly selected eligible patients) and all were interviewed to answer the questionnaire.

Sample collection. An volume of 5-gram stool samples was collected from each participant in a clean, dry, waterproof container containing no detergent, preservatives or transport media; the patients' fecal samples were either frozen for long periods (60 days) or refrigerated for short periods (48 hours). Sterile Plastic stool container and ELISA antibody kits (AccuDiag $^{\mathrm{TM}}$, Diagnostic Automation, Inc., California, USA) of $100 \%$ specificity and $0.5 \mathrm{Ng} / \mathrm{ml}$ sensitivity [See Appendix B] were used for the study, as well as Icebox for keeping the sample through transportation. A Deep freezer for specimen storage was prepared as well as ELISA Micro plate Reader (BIO-TEC) Germany.

Assay procedure and principle of the test. H. pylori antigen in stool sample was determined by the ELISA using a commercially available monoclonal antibody kit. Stool samples were diluted, added $(100 \mu \mathrm{l})$ to antibody-coated microwells and incubated for 30 minutes at room temperature. H. pylori-specific monoclonal antibodies were conjugated with the $H$. pylori antigens. All unbound materials were washed out (three time repeated washing process). Then enzyme conjugate was added (red color solution) and incubated for 30 minutes; after adding the enzyme, it was bound to the antibody-antigen complex. The excess enzyme conjugate was washed out also, and the Chromogenic substrate was added and incubated for 15 minutes. After the addition of the stop solution to stop the reaction, a visible yellow color reaction appeared indicating the presence of $H$. pylori. The intensity of the generated color was proportional to the amount of antigen in the sample. The results were read by a microwell reader compared in a parallel with a calibrator and controls. All the tests were performed according to the manufacturer's instructions. The diagnostic ELISA, HpSA test was used as a quantitative assay for detection of $H$. Pylori antigens in a human stool specimen. The estimation of the sample concentration depended upon the construction of a standard curve, so the standard curve absorbance (O.D $450 \mathrm{~nm}$ ) versus concentration of stool antigen in $\mathrm{ng} / \mathrm{ml}$ for the quantitative detection of the stool antigen in each sample was applied, according to the ELISA kit standard.

Serological tests for detection of IgG antibodies. Three $\mathrm{ml}$ venous blood was withdrawn from each participant at the time of delivering stool sample, then the blood was centrifuged at speed of 2200-2500 RPM (revolutions per minute) for 10 minutes to separate the serum that was analyzed immediately or was stored refrigerated at $\left(4-8^{\circ} \mathrm{C}\right)$ for up to 48 hours. For a longer storage, the serum was kept at $-20^{\circ} \mathrm{C}$ until analyzed for anti-H. pylori antibodies - IgG detection using Rapid anti-H. pylori kit (Advanced Quality ${ }^{\mathrm{TM}}$, InTec Products, INC, China).

Assay procedure and Principle of Rapid H. pylori IgG Test:

We brought the device, sample diluent, and specimens to room temperature. 
After we dispensed 1-2 drops $(10 \mu$ l each drop) of serum to the circular sample well of the test card using the plastic dropper.

We added two drops of sample diluent to the sample well immediately.

We interpreted test results at 15 minutes.

In positive results, we saw two lines, one of them referred to the control, while the other one referred to the infected individual.

The principle of the test used for detecting IgG antibodies in human serum or plasma is a visual, qualitative test. It was performed in a single-step procedure using one to two hanging drops of serum. The test was started with a sample applying to the sample kit and adding the provided sample diluent immediately. The $H$. pylori antigens-colloidal gold conjugate embedded in the sample pad reacted with the $H$. pylori antibody present in serum or plasma sample forming conjugate/ the $\mathrm{H}$. Pylori antibody complex. As the mixture was allowed to migrate along the test strip, the conjugate/ the $H$. pylori antibody complex was captured by an antibodybinding protein and immobilized on a membrane forming a colored test band in the test region. A negative sample did not produce a test line due to the absence of colloidal gold conjugate H. pylori antibody complex. A colored central band in the control region appeared at the end of test procedure regardless of test results. This control band was the result of colloidal gold conjugate binding to an anti-H. pylori antibody immobilized on the membrane. The control line indicated that the colloidal gold conjugate was functional. The absence of the control band evidenced that the test was invalid. HpSA should be used as the gold standard as the test offers excellent sensitivity and specificity compare to the invasive methods, such as gastric biopsy, culture, and the rapid urease test. [10].
Statistical analysis. The Data for prevalence and distribution of Helicobacter pylori infection among sexes and different age groups generated from the study and the association between the prevalence of $H$. pylori infection and risk factors were determined and tabulated as Microsoft Excelled sheets and uploaded to the Statistical Package for Social Sciences (SPSS version 18) Cross-tabulation of the variables were generated. Chi-square was used to detect a statistically significant correlation between the variables.

\section{Results}

Study sample description. The survey was carried on during the period from January to April 2017. One hundred and twenty-five different dyspeptic patients were included in our study to investigate the prevalence of H. pylori infection and its related risk factors. During this period, all patients were interviewed, and they answered the questionnaire regarding personal information and their lifestyle. At the same time samples of stool and blood were collected for investigations. The participants were living in different geographical areas of Tripoli; approximately 53\% of them were from Tajurah, 22\% - Tripoli central area and 17\%Ain-zarra area.

The following tables present a concise description of the study samples.

The study population age ranged from 1883 years old. $37.6 \%$ were males with a mean age of 40.22 years old, and $62.4 \%$ were females with a mean age of 39.10 years old. The male to female ratio was 1:1.66 (Table 1).

2. Detection of $H$. pylori infection by HpSA test

Table 2 presents the rate of positivity of H. pylori stool antigen test in adult dyspeptic

Table 1. Division of patients with dyspepsia by age and sex

\begin{tabular}{|c|c|c|c|c|c|c|}
\hline Age groups & Male No. & $\mathbf{\%}$ & Female No. & \% & Total No. & \% \\
\hline $18-27$ & 5 & 20.83 & 19 & 79.17 & 24 & 19.2 \\
\hline $28-37$ & 11 & 34.38 & 21 & 65.62 & 32 & 25.6 \\
\hline $38-47$ & 16 & 55.17 & 13 & 44.83 & 29 & 23.2 \\
\hline $48-57$ & 6 & 28.57 & 15 & 71.43 & 21 & 16.8 \\
\hline$>57$ & 9 & 47.37 & 10 & 52.63 & 19 & 15.2 \\
\hline Total & 47 & 37.6 & 78 & 62.4 & 125 & $100 \%$ \\
\hline
\end{tabular}

Table 2. Prevalence of $\boldsymbol{H}$. pylori infection by HpSA test

\begin{tabular}{|l|l|l|}
\hline Stool Ag. Detection & The result of $\boldsymbol{H}$. pylori stool Ag. No. & The result of $\boldsymbol{H}$. pylori stool Ag. \% \\
\hline
\end{tabular}

\begin{tabular}{|c|c|c|}
\hline Positive & 80 & $64 \%$ \\
\hline Negative & 45 & $36 \%$ \\
\hline Total No. & 125 & $100 \%$ \\
\hline
\end{tabular}


patients among 125 adult patients, who underwent HpSA test. In (64\%) 80 patients it was positive.
3. Detection of $H$. pylori infection by IgG test Table 3 showed that the prevalence of $H$. pylori infection by IgG was $70.4 \%$.

Table 3. Prevalence of $\boldsymbol{H}$. pylori infection by IgG test

\begin{tabular}{|c|c|c|}
\hline $\begin{array}{c}\text { IgG Antibody } \\
\text { detection }\end{array}$ & $\begin{array}{c}\text { The result of } \boldsymbol{H} \text {. pylori IgG Test } \\
\text { in No. }\end{array}$ & $\begin{array}{c}\text { The result of } \boldsymbol{H} \text {. pylori IgG test } \\
\text { in } \%\end{array}$ \\
\hline Positive & 88 & $70.4 \%$ \\
\hline Negative & 37 & $29.6 \%$ \\
\hline Total No. & 125 & $100 \%$ \\
\hline
\end{tabular}

4. Stool antigen testing versus serology (IgG)

4.1. Comparison of frequency HpSA test (gold standard) and IgG test.

Comparison of stool antigen detection test with serology (Table 4.1) revealed that among 80 stool antigen positive cases, 64 (80\%) were positive by IgG. 24 (53\%) were positive for IgG out of 45 stool antigen-negative cases. This difference was statistically significant at $P=0.002$.

4.2. Accuracy of IgG test

Table 4.2 proved that sensitivity of the IgG test was $80 \%$, while the specificity was $46.7 \%$, total agreement (accuracy) 68\%, PPV=72.7\%, and NPV $=56.8 \%$.

Table 4.1. Comparison of frequency HpSA test (gold standard) and IgG test

\begin{tabular}{|c|c|c|c|c|}
\hline Test & HpSA positive No. & HpSA negative No. & Total No. & $\boldsymbol{P}$ value \\
\hline IgG positive No. & 64 & 24 & 88 & \multirow{2}{*}{0.002} \\
\hline IgG negative No. & 16 & 21 & 37 & 125 \\
\hline Total No. & 80 & 45 & \\
\hline
\end{tabular}

Table 4.2. IgG Test *HPSA Test Cross tabulation.

\begin{tabular}{|c|c|c|c|}
\hline & \multicolumn{2}{|c|}{ HPSA TEST } & \multirow{2}{*}{ Total } \\
\cline { 2 - 3 } & Positive & Negative & 88 \\
\hline IgG test Positive No. & 64 & 24 & $100.0 \%$ \\
\%within IgG test & $72.7 \%$ & $27.3 \%$ & $70.4 \%$ \\
\hline \%within HPSA test & $80.0 \%$ & $53.3 \%$ & 37 \\
IgG Test Negative No. & 16 & 21 & $100.0 \%$ \\
\%within IgG test & $43.2 \%$ & $56.8 \%$ & $29.6 \%$ \\
\%within HPSA test & $20.0 \%$ & $46.7 \%$ & 125 \\
\%within IgG test & 80 & 45 & $100.0 \%$ \\
\%within HPSA test & $64.0 \%$ & $36.0 \%$ & $100.0 \%$ \\
\hline
\end{tabular}

4.3. Correlations of HpSA and IgG tests with the age, marital status, monthly income, and family number risk factors

From the table above, the significant correlation of HpSA test with the age, marital status, and monthly income is evident, while IgG was positively correlated with the marital status and family number.

5. Socio-demographic characteristics of study participants

5.1. Personal risk factors

Prevalence of $H$. pylori among some associated risk factors of the study participants (Table 5.1). The Correlation is significant at the level of 0.01 (2-tailed) regarding age $(p=0.004)$ and 0.05 (2-tailed) regarding marital status risk factors $(p=0.033)$. While there is no significant correlation between HpSA positivity and, gender $(p=0.976)$, job $(p=0.430)$ and educational level $(p=0.819)$.

5.2. Effects of socioeconomic status

Table 5.2 proved that the correlation was significant at the level of 0.05 for the monthly income $(p=0.028)$; however, there is no correlation between the number of people living in each household $(p=0.086)$ and sources of water $(p=0.716)$.

5.3. Lifestyle variables, Family history of gastroduodenal disease and drug Consumption

Table 5.3 showed that there is no significant correlation between the rate of $H$. pylori infection 
Table 4.3. Pearson Correlations of the HpSA and IgG tests with some of the risk factors

\begin{tabular}{|c|c|c|c|c|c|c|}
\hline Col & elations & HpSa & IgG & $\begin{array}{l}\text { Age of the } \\
\text { tested }\end{array}$ & Marital & Monthly \\
\hline HpSA Test & Pearson Correlation & 1 & $0.280^{* *}$ & $-0.256^{* *}$ & $-0.191^{*}$ & $-0.197^{\star}$ \\
\hline & Sig. (2-tailed) & & 0.002 & 0.004 & 0.033 & 0.028 \\
\hline & $\mathrm{N}$ & 125 & 125 & 125 & 125 & 125 \\
\hline IgG Test & Pearson Correlation & $0.280^{\star \star}$ & 1 & -0.116 & $-0.272^{* *}$ & -0.090 \\
\hline & Sig. (2-tailed) & 0.002 & & 0.199 & 0.002 & 0.320 \\
\hline & $\mathrm{N}$ & 125 & 125 & 125 & 125 & 125 \\
\hline Age of the tested & Pearson Correlation & $-0.256^{* *}$ & -0.116 & 1 & $0.483^{* *}$ & 0.077 \\
\hline group & Sig. (2-tailed) & 0.004 & 0.199 & & 0.000 & 0.393 \\
\hline & $\mathrm{N}$ & 125 & 125 & 125 & 125 & 125 \\
\hline Marital status & Pearson Correlation & $-0.191^{*}$ & $-0.272^{* *}$ & $0.483^{* *}$ & 1 & -0.035 \\
\hline & Sig. (2-tailed) & 0.033 & 0.002 & 0.000 & & 0.694 \\
\hline & $\mathrm{N}$ & 125 & 125 & 125 & 125 & 125 \\
\hline Monthly income & Pearson Correlation & $-0.197^{*}$ & -0.090 & 0.077 & -0.035 & 1 \\
\hline & Sig. (2-tailed) & 0.028 & 0.320 & 0.393 & 0.694 & \\
\hline & $\mathrm{N}$ & 125 & 125 & 125 & 125 & 125 \\
\hline FAMILY NO. & Pearson Correlation & 0.154 & $0.224^{*}$ & 0.132 & $-0.253^{* *}$ & -0.001 \\
\hline & Sig. (2-tailed) & 0.086 & 0.012 & 0.143 & 0.004 & 0.988 \\
\hline & $\mathrm{N}$ & 125 & 125 & 125 & 125 & 125 \\
\hline
\end{tabular}

Notes. ** - correlation was significant at the 0.01 level (2-tailed);

* - correlation was significant at the 0.05 level (2-tailed).

Table 5.1 Personal risk factors

\begin{tabular}{|c|c|c|c|c|c|}
\hline Variable & $\begin{array}{c}\text { Negative No. } \\
\text { HpSA }\end{array}$ & $\%$ & Positive No. HpSA & $\%$ & $P$ value \\
\hline $\begin{array}{c}\text { Age: } \\
18-27 \\
28-37 \\
38-47 \\
48-57 \\
>57\end{array}$ & $\begin{array}{l}15 \\
12 \\
9 \\
4 \\
5\end{array}$ & $\begin{array}{l}62.5 \% \\
37.5 \% \\
31.0 \% \\
19.0 \% \\
26.3 \%\end{array}$ & $\begin{array}{c}9 \\
20 \\
20 \\
17 \\
14\end{array}$ & $\begin{array}{l}37.5 \% \\
62.5 \% \\
69.0 \% \\
81.0 \% \\
73.7 \% \\
\end{array}$ & 0.004 \\
\hline $\begin{array}{c}\text { Sex: } \\
\text { Male } \\
\text { Female }\end{array}$ & $\begin{array}{l}17 \\
28 \\
\end{array}$ & $\begin{array}{l}36.2 \% \\
35.9 \% \\
\end{array}$ & $\begin{array}{l}30 \\
50\end{array}$ & $\begin{array}{l}63.8 \% \\
64.1 \% \\
\end{array}$ & 0.976 \\
\hline $\begin{array}{c}\text { Marital status: } \\
\text { Single } \\
\text { Married }\end{array}$ & $\begin{array}{l}14 \\
31 \\
\end{array}$ & $\begin{array}{l}53.9 \% \\
31.3 \% \\
\end{array}$ & $\begin{array}{l}12 \\
68 \\
\end{array}$ & $\begin{array}{l}46.2 \% \\
68.7 \% \\
\end{array}$ & 0.033 \\
\hline $\begin{array}{c}\text { Occupational } \\
\text { status: } \\
\text { Employee } \\
\text { Housewife } \\
\text { Private } \\
\text { Student } \\
\end{array}$ & $\begin{array}{c}15 \\
15 \\
7 \\
8 \\
\end{array}$ & $\begin{array}{l}34.1 \% \\
34.9 \% \\
28.0 \% \\
61.5 \% \\
\end{array}$ & $\begin{array}{c}29 \\
28 \\
18 \\
5\end{array}$ & $\begin{array}{l}65.9 \% \\
65.1 \% \\
72.0 \% \\
38.5 \%\end{array}$ & 0.430 \\
\hline $\begin{array}{c}\text { Education level: } \\
\text { Higher } \\
\text { Intermediate } \\
\text { Low }\end{array}$ & $\begin{array}{l}12 \\
19 \\
14 \\
\end{array}$ & $\begin{array}{l}36.4 \% \\
33.9 \% \\
38.9 \% \\
\end{array}$ & $\begin{array}{l}21 \\
37 \\
22 \\
\end{array}$ & $\begin{array}{l}63.6 \% \\
66.1 \% \\
61.1 \% \\
\end{array}$ & 0.819 \\
\hline
\end{tabular}


and smoking $(p=0.357)$, diseased family history $(p=0.131)$ and drug consumption $(p=0.363)$.

H. pylori infection distribution according to the blood groups
Table 5.4 showed that there is no significant statistical correlation between the rate of H. pylori infection and blood groups despite higher prevalence rate among blood group $\mathrm{O}$.

Table 5.2. Effects of socioeconomic status

\begin{tabular}{|l|c|c|c|c|c|}
\hline \multicolumn{1}{|c|}{ Variable } & $\begin{array}{c}\text { HpSA negative } \\
\text { No. }\end{array}$ & $\%$ & $\begin{array}{c}\text { HpSA positive } \\
\text { No. }\end{array}$ & $\%$ & $P$ Value \\
\hline Monthly income LD: & 23 & $42.6 \%$ & 31 & $57.4 \%$ & 0.028 \\
$<1000$ & 20 & $38.5 \%$ & 32 & $61.5 \%$ & \\
$1000-2000$ & 2 & $10.5 \%$ & 17 & $89.5 \%$ & \\
$>2000$ & 10 & $31.3 \%$ & 22 & $68.8 \%$ & 0.086 \\
\hline Number of people in Household: & 22 & $31.0 \%$ & 49 & $69.0 \%$ & \\
$1-4$ & 13 & $59.1 \%$ & 9 & $40.9 \%$ & \\
$5-8$ & & & & & \\
$>8$ & 9 & $27.3 \%$ & 24 & $72.7 \%$ & 0.716 \\
\hline Sources of water for drinking: & 16 & $48.5 \%$ & 17 & $51.5 \%$ & \\
Piped water and gallon & 20 & $33.9 \%$ & 39 & $66.1 \%$ & \\
Well & & & & \\
Filtered water (Tahlia) & \multicolumn{2}{|l}{}
\end{tabular}

Table 5.3. Lifestyle variables, family history of the gastroduodenal disease and drug consumption

\begin{tabular}{|l|c|c|c|c|c|}
\hline \multicolumn{1}{|c|}{ Variable } & $\begin{array}{c}\text { HpSA Negative } \\
\text { No. }\end{array}$ & $\%$ & $\begin{array}{c}\text { HpSA Positive } \\
\text { No. }\end{array}$ & $\%$ & $\boldsymbol{P}$ Value \\
\hline Smoking: & 37 & $38.14 \%$ & 60 & $61.86 \%$ & 0.357 \\
No & 8 & $28.57 \%$ & 20 & $71.43 \%$ & \\
Yes & & & & & \\
\hline $\begin{array}{l}\text { Family History of Peptic ulcer or } \\
\text { Malignancy: }\end{array}$ & 38 & $39.58 \%$ & 58 & $60.42 \%$ & 0.131 \\
No & 7 & $24.14 \%$ & 22 & $75.86 \%$ & \\
Yes & & & & & \\
\hline Consumed drugs: & 39 & $35.14 \%$ & 72 & $64.86 \%$ & 0.363 \\
No & 6 & $42.86 \%$ & 8 & $57.14 \%$ & \\
Yes & & & & \\
\hline
\end{tabular}

Table 5.4. H. pylori infection distribution according to the blood groups

\begin{tabular}{|c|c|c|c|c|}
\hline Blood group & HpSA positive test No. & HpSA negative test No. & Total No. & $\boldsymbol{P}$ value \\
\hline A & 24 & 17 & 41 & 0.761 \\
\hline B & 20 & 8 & 28 & 0.819 \\
\hline AB & 3 & 0 & 3 & \\
\hline O & 33 & 20 & 53 & 0.865 \\
\hline Total & 80 & 45 & 125 & \\
\hline
\end{tabular}

\section{Discussion}

The accurate diagnosis and management become a vital strategy for facing the H. pylori challenge because of its strong association with gastroduodenal diseases as well as its high rate of infectivity especially in the developing countries. Although many diagnostic tests have been developed for detecting $H$. pylori, all have advantages as well as disadvantages. However, Breath tests or fecal antigen tests are considered the best because of their excellent accuracy, as well as they are simple and non-invasive. In the study, HpSA was used as a proxy reference test for detection of $H$. pylori infection. As reported by many international studies, it was an accurate and a reliable test in comparison with the invasive tests and Urea Breath Test for detection of active infection of $H$. pylori pathogen [13-19]; moreover, to our best knowledge, there are no previous reports of assessing $H$. pylori infection 
rates by stool antigen test in Tripoli-Libya. To avoid variations in polyclonal antibodies, we used a kit that included monoclonal antibodies specific for $H$. pylori antigens to assess the presence of $H$. pylori. Monoclonal antibodies looked more accurate than polyclonal antibodies as it was documented by many studies [20]. Our study focused mainly on determining the rate of $H$. pylori infection by HpSA test in adult dyspeptic patients of Tripoli city, moreover, evaluating some of the potential risk factors associated with $H$. pylori infection, in addition, comparing HpSA test with the serological IgG test. Overall, 125 patients were involved in this study. The results proved that the age of the studied population ranged from 18-83 years old, with a mean age (40.22) (Table 5.1). It was established that the majority of the examined patients were infected with $H$. pylori according to HpSA findings. The infection rates were increasing with age and married subjects (Table 5.6). Two non-invasive tests, HpSA test - the gold standard one, were used in this study to evaluate $H$. pylori infection as well as (IgG) test for comparison. The study proved that the stool antigen assay (HpSA) has showed promising results for detection of $H$. pylori antigen in stool samples.

\section{Conclusions}

The study proved that $H$. pylori infection was a serious health problem in the Tripoli area. The rate of $\mathrm{H}$. pylori infection among 125 adult dyspeptic subjects undergoing Stool antigen test was relatively high (64\%). Most affected patients were at the age of 28-47 years old. It was more common in married subjects than single. The most significant risk factors for $H$. pylori infection was (age, marital status, and socio-economic state). Sex, smoking, occupation, education level, number of persons in each home, water consumed, family history of peptic ulcer or gastric malignancy, drug consumption and blood group could not be considered as risk factors of $H$. pylori infection as evidenced by the results of our study in Tripoli population.
Finally, HpSA test is comparatively inexpensive, noninvasive, simple and accurate test for detecting $H$. pylori in a stool sample. SATs using monoclonal antibodies are useful for primary diagnosis as well as for the assessment of eradication therapy.

\section{Recommendations}

According to the findings of the study the following recommendations can be shaped. There was a high prevalence rate of $H$. pylori infection in dyspeptic patients of this study area, so high attention should be paid by governments, local administration, and district health sector. They should contribute health education to increase the knowledge of society about $H$. pylori transmission, besides, the quality of water could be tested for $\mathrm{H}$. pylori, and there is an urgent need to provide a wellprotected and treated drinking water to the community. Creating good awareness on $\mathrm{H}$. pylori infection and its risk factor is essential because the majority of respondents have no awareness about $H$. Pylori and its risk factors, and they use any water source without care, they possess no information about the transmission pathway of $H$. pylori and its outcome.

Additionally, this study involved only stool test and questionnaire survey, so it is recommended that further studies must be carried out using different testing methods such as Urea Breath Test or Rapid Urease Test with a high number of patients.

\section{Funding}

This research received no external funding.

\section{Conflict of Interests}

The authors declare no conflict of interest.

\section{Author Contributions}

Goma M. Huwiage - supervision, writing review and editing, validation, data curation, Abdurrazag A. Nami - conceptualization, visualization, methodology, writing original draft, Ali Hussein Akadh - project administration, resources, software, formal analysis, investigation, funding acquisition. 


\title{
ВИЗНАЧЕННЯ HЕLICOBACTER PYLORI ЗА ДОПОМОГОЮ КАЛОВОГО АНТИГЕННОГО ТЕСТУ (НРSА) У ДОРОСЛИХ ПАЦІЕНТІВ 3 ДИСПЕПСИЧНИМИ РОЗЛАДАМИ У ТРІПОЛІ, ЛІВІЯ
}

\author{
G.M. Huwiage ${ }^{1}$, A.A. Nami' ${ }^{2}$, A.H. Akadh ${ }^{3}$ \\ 1 - HIGH INSTITUTE OF MEDICAL SCIENCES\& TECHNOLOGY, ALGARABOLLI, LIBYA \\ 2 - AL-MERGIB UNIVERSITY, AL KHUMS, LIBYA \\ 3 - MEDITERRANEAN SPECIALIZED CLINICS, TRIPOLI, LIBYA
}

\begin{abstract}
Вступ: Тісний зв'язок Helicobacter pylori з диспепсичними розладами, виразковою хворобою та раком шлунка підтверджено багатьма дослідженнями.

Мета роботи: встановити взаємозв'язок між диспепсичними розладами, позитивними результатами калового антигенного тесту та серологічної діагностики IgG на H. pylori.

Методи: Обстежено 125 дорослих пацієнтів з диспепсичними розладами (які лікувалися у гастроентерологічних відділень Mediterranean ma Tajurah лікарень Тріполі) за допомогою: ІФА на визначення антигенів у калі та визначення у сироватці крові IgG антитіл до H. Pylori. Cmamuстичну обробку отриманих даних проводили за допомогою програмного забезпечення SPSS.

Результати: Серед 125 пацієнтів з диспепсичними розладами (47 чоловіків та 78 жінок віком від 18 до 83 років) у 80 встановлено наявність Н. pylori за результатами калового антигенного тесту, у 88 осіб - позитивний серологічний тест на IgG. Серед пацієнтів з позитивним результатами переважають особи віком 28-47 років. Встановлено взаємозв'язок з такими факторами як вік, сімейний статус та економічне становище. Не було достовірно значимих взаємозв'язків між Н. pylori інфекцією та статтю, джерелами питної води, стандартами життя, палінням, сімейним анамнезом виразкової хвороби, вживанням лікарських засобів та групою крові.

Висновки: Високий відсоток частоти визначення Н. pylori за допомогою HрSA калового антигенного тесту вказує, що такий метод - надійний, недорогий та неінвазивний - може слугувати для діагностики активності інфекції та моніторингу динаміки лікування. В той час, як серологічна діагностика IgG до H. pylori через нижчу чутливість, специфічність та точність може застосовуватися у якості скринінгу.

КЛЮЧОВІ СЛОВА: Helicobacter pylori; диспепсія; імуноферментний аналіз; каловий антигенний тест.
\end{abstract}

\section{Information about authors}

Goma Mohamed Huwiage-Ph.D., Assistant Professor, Department of Medical Microbiology, High Institute of Medical Sciences\& Technology, Algarabolli, Libya.

ORCID 0000-0002-2727-148X, e-mail: gomanagoma96@yahoo.com

Abdurrazag Altaher Nami - Ph.D., Assistant Professor, Department of Biology Faculty of Arts\& Sciences, Al-mergib University, Libya.

ORCID 0000-0002-1076-4368, e-mail: abdnami@gmail.com

Ali Hussein Akadh - MSc in Medical Microbiology, Mediterranean specialized clinics, Tripoli, Libya.

ORCID0000-0002-5439-7774, e-mail: alialhullali1955@gmail.com

\section{References}

1. Asaka M, Sepulveda AR, Sugiyama T, Graham DY. Gastric cancer. In: Helicobacter pylori: physiology and genetics 2001. ASM Press.

2. Longo D, Fauci A. Harrison's Gastroenterology and Hepatology, 2e. McGraw-Hill Education; 2013.

3. Marcus EA, Scott DR. Gastric colonization by H. pylori. In: Helicobacter pylori. 2016 (pp. 23-34). Springer, Singapore.

doi: 10.1007/978-981-287-706-2_2

4. Moran AP. 10 Lipopolysaccharides of Helicobacter pylori: Importance in Gastric Adaptation and Pathogenesis. Helicobacter Pylori in the 21st Century. 2010;17:190.

doi: $10.1079 / 9781845935948.0190$

5. Alm RA, Noonan B. The Genome. In: Mobley HLT, Mendz GL, Hazell SL, editors. Helicobacter pylori: Physiology and Genetics. Washington (DC): ASM Press; 2001. Chapter 27

6. Kim JM. H. pylori Virulence Factors: Toxins (CagA, VacA, DupA, OipA, IceA). In: Helicobacter pylori 2016 (pp. 77-88). Springer, Singapore. doi: 10.1007/978-981-287-706-2_5 
7. Kim N. Prevalence and transmission routes of H. pylori. In: Helicobacter pylori 2016 (pp. 3-19). Springer, Singapore.

doi: 10.1007/978-981-287-706-2_1

8. Plonka M, Targosz A, Brzozowski T. Can Drinking Water Serve as a Potential Reservoir of Helicobacter pylori? Evidence for Water Contamination by Helicobacter pylori. In: Trends in Helicobacter pylori Infection 2014 Apr 3. IntechOpen.

doi: $10.5772 / 57568$

9. Sutton $\mathrm{P}$, Mitchell $\mathrm{H}$, editors. Helicobacter pylori in the 21st Century. CABI; 2010.

doi: $10.1079 / 9781845935948.0000$

10. Walker BR, Colledge NR. Davidson's principles and practice of medicine e-book: With STUDENT CONSULT Online Access. Elsevier Health Sciences; 2013 Dec 6. P. 872-8.

11. Kim SE. Functional Dyspepsia. In: Helicobacter pylori, 2016 (pp. 207-218). Springer, Singapore.

doi: 10.1007/978-981-287-706-2_18

12. Yang HR. Updates on the diagnosis of Helicobacter pylori infection in children: what are the differences between adults and children? Pediatric Gastroenterology, Hepatology \& Nutrition. 2016 Jun 1;19(2):96-103.

doi: 10.5223/pghn.2016.19.2.96

13. Dore MP, Pes GM, Bassotti G, Usai-Satta P. Dyspepsia: when and how to test for Helicobacter pylori infection. Gastroenterology Research and Practice. 2016;2016.

doi: $10.1155 / 2016 / 8463614$

14. El-Shabrawi M, El-Aziz NA, El-Adly TZ, Hassanin F, Eskander A, Abou-Zekri M, Mansour H, Meshaal S. Stool antigen detection versus 13C-urea breath test for non-invasive diagnosis of pediatric Helicobacter pylori infection in a limited resource setting. Archives of Medical Science: AMS. 2018 Jan;14(1):69-73.

doi: 10.5114/aoms.2016.61031
15. Iranikhah A, Ghadir MR, Sarkeshikian S Saneian H, Heiari A, Mahvari M. Stool antigen tests for the detection of Helicobacter pylori in children. Iranian Journal of Pediatrics. 2013 Apr;23(2):138-42.

16. Calik Z, Karamese M, Acar O, Karamese SA, Dicle Y, Albayrak F, Can S, Guvendi B, Turgut A, Cicek M, Yazgi H. Investigation of Helicobacter pylori antigen in stool samples of patients with upper gastrointestinal complaints. Brazilian Journal of Microbiology. 2016 Mar;47(1):167-71.

doi: 10.1016/j.bjm.2015.11.022

17. Asaka M, Kato M, Takahashi SI, Fukuda $Y$, Sugiyama T, Ota H, Uemura N, Murakami K, Satoh K, Sugano K. Guidelines for the management of Helicobacter pylori infection in Japan: 2009 revised edition. Helicobacter. 2010 Feb;15(1):1-20.

doi: 10.1111/j.1523-5378.2009.00738.x

18. Kalach N, Gosset P, Dehecq E, Decoster A, Georgel AF, Spyckerelle C, Papadopoulos S, Dupont C, Raymond J. A one-step immune-chromatographic Helicobacter pylori stool antigen test for children was quick, consistent, reliable and specific. Acta Paediatrica. 2017 Dec;106(12):2025-30.

doi: 10.1111/apa.13968

19. Tameshkel FS, Niya MH, Kheyri Z, Azizi D, Roozafzai F, Khorrami S. The evaluation of diagnostic and predictive values of Helicobacter pylori stool antigen test in Iranian patients with dyspepsia. Iranian Journal of Pathology. 2018;13(1):3838-44.

doi: 10.30699/ijp.13.1.39

20. Zhou. X, Su. J, Xu. G\& Zhang, G. Accuracy of stool antigen test for the diagnosis of Helicobacter pylori infection in children: a meta-analysis. Clinics and research in Hepatology and gastroenterology, Oct 2014; 38 (5), 629-38.

doi: 10.1016/j.clinre.2014.02.001

Received 07 August 2019; revised 20 October 2019; accepted 23 November 2019

This is open access article distributed under the Creative Commons Attribution License, which permits unrestricted use, distribution, and reproduction in any medium, provided the original work is properly cited. 